\title{
Preparation Process and 0ptimization Design for Composites Rudderpost in the Long-Time High Temperature Environment
}

\author{
Li Jing, Changwan Min, Geliang Sun, Bin Fu, Min Chen, Zhanwei Cao \\ Science and Technology on Space Physics Laboratory, Beijing, China \\ Email: jingli315@163.com
}

How to cite this paper: Jing, L., Min, C.W., Sun, G.L., Fu, B., Chen, M. and Cao, Z.W. (2017) Preparation Process and Optimization Design for Composites Rudderpost in the Long-Time High Temperature Environment. Journal of Materials Science and Chemical Engineering, 5, 69-75.

http://dx.doi.org/10.4236/msce.2017.51010

Received: October 12, 2016

Accepted: January 1, 2017

Published: January 4, 2017

\begin{abstract}
Rudder is an important part for the glider aircraft. In order to satisfy the longtime high-velocity for the near-space vehicle in the atmosphere, the lightweight, high-stiffness and high-strength all-composites rudderpost is required urgently to be prepared. The all-composites rudderpost can keep high rudder efficiency in the high temperature environment. Based on the technique requirement of high-performance composites rudder, a $3 \mathrm{D} \mathrm{C} / \mathrm{SiC}$ rudderpost was manufactured by the CVI-CMC-SiC [1] processes. It was found during rudderpost testing that the high-temperature mechanical properties decreased and had large discretization. The analysis of the failure mechanisms was conducted by FTA method to recognize the failure modes and main reasons for rudderpost abnormal fracture and to reproduce the fracture phenomenon, which could guide production company to modify their preparation process control. Then the modified processes were proved to be validated. And the stability and reliability of the production performances were improved.
\end{abstract}

\section{Keywords}

Rudderpost, Preparation Process, FTA, Optimization Design, Optimization Manufacture

\section{Introduction}

The rudder is an important part of the aircraft. In order to meet the requirements of long-time high-speed aircraft in the atmosphere, the development of light, high strength rudderpost, which can still maintain high efficiency and high stiffness under high temperature conditions, is urgently needed.

Finally, complete content and organizational editing before formatting. Please 
take note of the following items when proofreading spelling and grammar:

The requirement of high performance composite rudder is proposed according to productor designer's requests (including the maximum load, the working temperature, the torsion angle, dimension, CVI-CMC-SiC) and the manufacturing technology at present [2]. The production test of rudderpost is carried out after adopting 3D preform, CVI-SiC densification, on-line rough machining, molten silicon leaching the infiltration process, and high density CVI-SiC [3].

\section{Problem Description}

To study the force and heat of the rudderpost, 1\#, 2\# and 3\# rudderpost samples were prepared, and the test parts installation is shown in Figure 1 [4].

The specific conditions of the experiment are as follows:

1) $1 \#$ rudderpost was tested for static strength at room temperature. The maximum torque load reached the required value, but rudderpost was not damaged. After that, the $1 \#$ rudderpost was used for the pre-testing of quartz lamp heating experiments. So $1 \#$ rudderpost had experienced a high temperature environment for a long time.

2) 2\# rudderpost was used for the force and thermal test. The load of the test sample didn't reach the required values at high temperature, which showed some problems with the sample.

3) 1\# rudderpost was used again. Firstly the 1\# rudderpost was loaded to torque value at room temperature static test requirements, and it was not destroyed. Then thermo-mechanical test, temperature curve was same with that of 2\# rudderpost. The load of $1 \#$ sample didn't reach the required value, either.

4) 3\# rudderpost was tested. In the room temperature static test, the torque was not loaded to the required value and $3 \#$ rudderpost fractured; the failure angle was also larger than the required value. Results show 3 fracture cracks: 2 cracks are $45^{\circ}$ to the axis and 1 crack is $0^{\circ}$ to the axis. There are 3 pieces of fractured parts and a crack at fixed points goes through 2 pin holes with a $0^{\circ}$ angle to the axis.

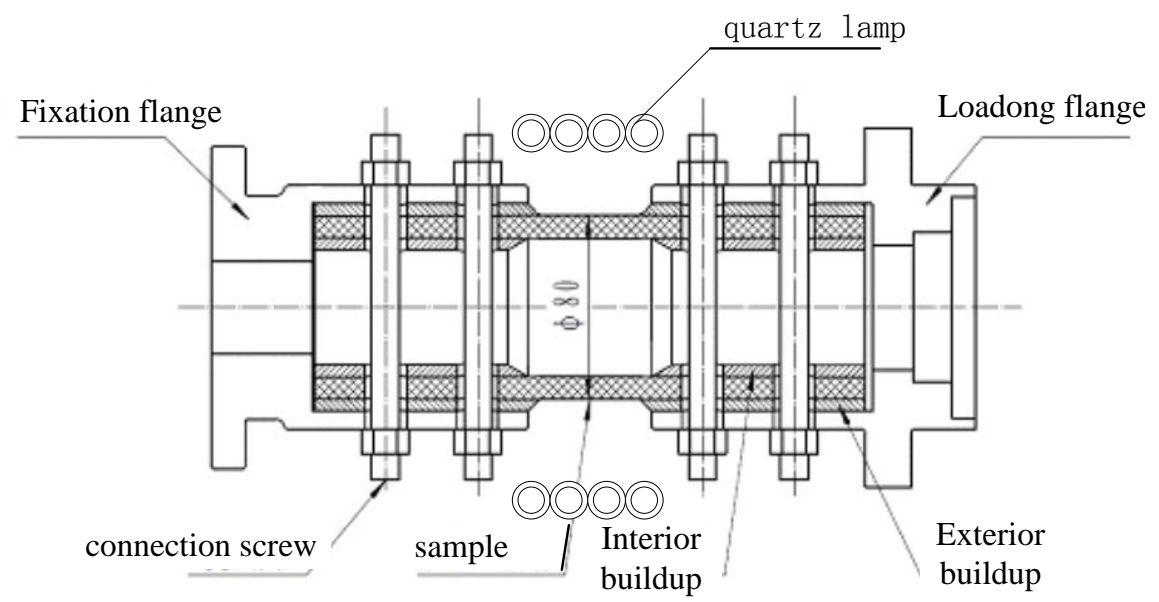

Figure 1. Schematic diagram of the test parts installation. 


\section{Production Quality Defect Analysis}

\subsection{Problem Location}

The issues of quality control of the rudderpost test parts are located at 2 aspects: one is the decreasing of mechanical properties at high temperature; the second is the large discretization of the mechanical properties of the rudderpost.

\subsection{Quality Defect Fault Tree}

As to the FTA method, the $\mathrm{C} / \mathrm{SiC}$ rudderpost production quality defects are considered as the top event, the fault tree is established for detailed investigation and analysis of failure. If production equipment and production documents are well and completed, the recording of processes are reliable and accurate (including the process cards, production records, performance test report). Supposed the vapor deposition layer of $\mathrm{C} / \mathrm{C}$ interface is thin, this layer cannot block carbon fiber oxidation or other reactions which injury in the process of $\mathrm{SiC}$ in subsequent vapor deposition.

Fault tree of rudderpost quality defect is shown in Figure 2, and the following conclusions are obtained:

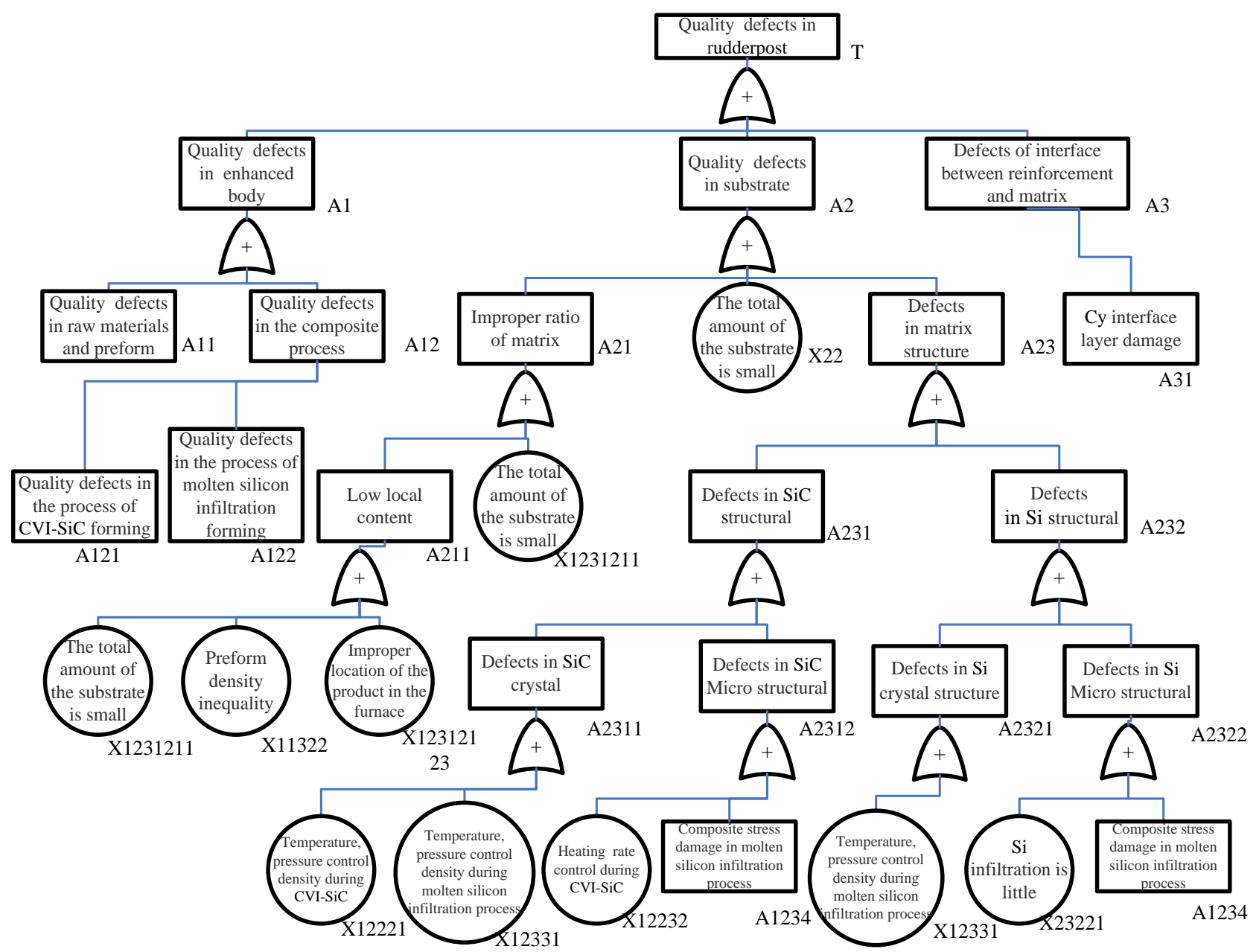

Figure 2. Fault tree of rudderpost quality. 
1) The bottom events "The total amount of the substrate is small", "Preform density inequality", "Improper location of the products in the furnace for CVICy and CVI-SiC processes", appear several times in the fault tree. They are important events to control the quality of the rudderpost;

2) The bottom event "Silicon infiltration amount is too large for molten silicon infiltration process [5]" is found in the fault tree. This event may be the key issue of product quality defects, and it appears many times and is of a certain possibility. It is needed to confirm the impact and take some control measurements.

\subsection{Mechanism Analysis}

Based the analysis above, that causes and mechanism for $\mathrm{C} / \mathrm{SiC}$ rudderpost poor mechanical properties under high temperature conditions are: post densification of rudderpost by molten silicon infiltration process, the rudderpost material compound containing too much silicon, whose melting point is only $1410^{\circ} \mathrm{C}$ and result in the vicinity of modulus rapid decreasing for the low melting point of material, and thus a decreasing in mechanical properties of the material.

The reasons for rudderpost's targe dispersion in mechanical properties are very complex: first, raw materials into the factory weren't performed detection and products' CT test shown obvious uneven density, showed as Figure 3; second, due to product density, different structure size and position in the furnace, the amount of CVI-Cy should be different in test. Electron microscopy showed that the fiber and the matrix fracture flush phenomenon (Figure 4), and the fiber damaging in the composite. Products' deposition positions in furnace were different, but the placements weren't recorded. Finally, the rudderposts were of lower density than the samples made from the same preform, and mechanical properties of the final product were low and scattered. In addition, because the final product density unchanged, resulting in much Si infiltration, metallographic pictures show the erosion carbon fiber by Si (Figure 4).

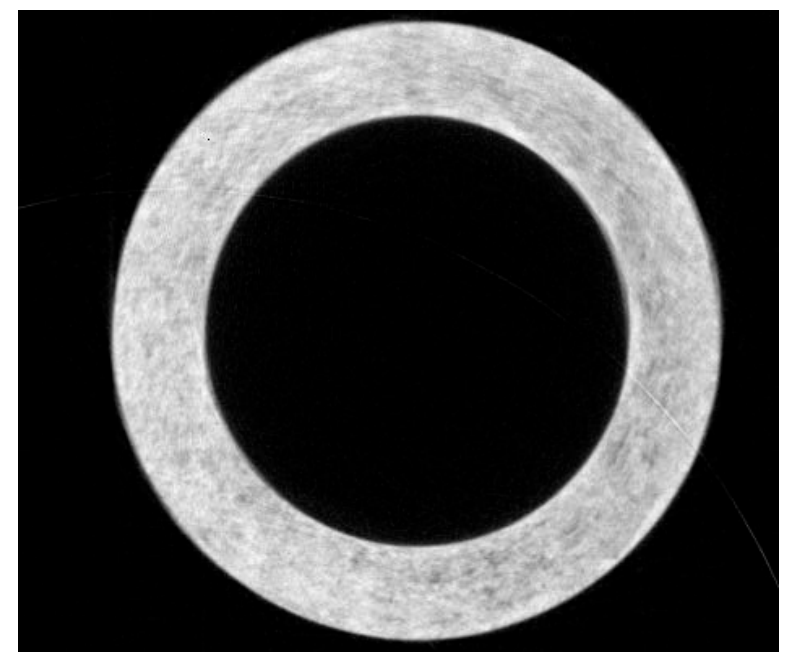

Figure 3. Detection of the residual part of the rudderpost test piece. 


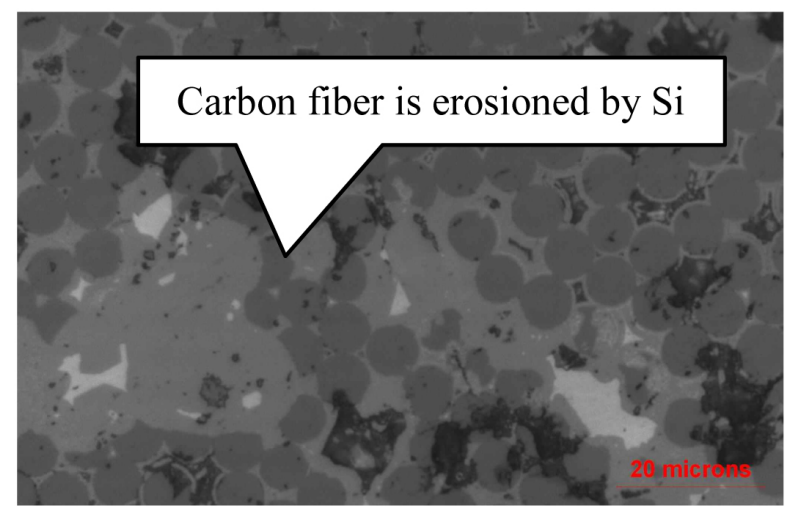

Figure 4. Metallographic scanning results of the rudderpost test specimens.

\subsection{The Problem of Repetition}

The production cycle of the rudderpost is long and it is difficult to repeat the production process. So the residual stress test is used to simulate replication instead. Two batches of test samples' size and raw materials are same, comparative test results are shown in Table 1. The rudderpost's surface quality has problems and the shear strength and three-point-bending strength are low. The results are consistent with the abnormal phenomenon of comparative samples and process state differences are the main factors leading to abnormal fracture.

\section{Measures and Verification}

\subsection{Improvement Measures}

Major process improvements are as follows, and have been cleared in the production instruments.

1) Introduce the non-destructive testing for the raw materials;

2) With the virtual simulations of the flow in the furnace, ensure that the furnace flow field be uniform, and the products' positions be recorded;

3) The product's density should be measured after CVI/SiC deposition process and before molten silicon infiltration process;

4) Temperature and pressure in the procedure has a great impact to the product quality and should be controlled carefully.

\subsection{Validation of the Improvement}

Three test samples were made under improved procedure, and the similar experiments were carried out again.

The mechanical properties were tested at room temperature, shown in Table 2. It proves that three-point-bending strength is improved more than $63 \%$.

All three improved rudderpost were not damaged, which show their excellent properties, shown in Table 3.

According to the design requirements of the rudderpost bending moment ( $L=$ required value), three test data samples mean $\bar{x}$ and sample standard deviation $s: \bar{X}=437.3, s=120.6$. 
Table 1. Comparison of three-point-bending test results of test pieces.

\begin{tabular}{cccccc}
\hline Test items & $\begin{array}{c}\text { The } \\
\text { rudderposts }\end{array}$ & $\begin{array}{c}\text { The density } \\
\text { after CVI-SiC } \\
\left(\mathrm{g} / \mathrm{cm}^{3}\right)\end{array}$ & $\begin{array}{c}\text { Sampling } \\
\text { quantity }\end{array}$ & $\begin{array}{c}\text { Intensity mean } \\
\text { value } \\
(\mathrm{MPa})\end{array}$ & $\begin{array}{c}\text { Dispersion } \\
\text { coefficient } \\
(\%)\end{array}$ \\
\hline $\begin{array}{c}\text { Surface } \\
\text { shear }\end{array}$ & $\begin{array}{c}\text { contrast } \\
\text { rudderpost }\end{array}$ & $\begin{array}{c}\text { prescriptive } \\
\text { value }\end{array}$ & 6 & $\begin{array}{c}\text { required value } \\
+2.34\end{array}$ & 10 \\
& rudderpost & $\begin{array}{c}\text { prescriptive } \\
\text { value }-1\end{array}$ & 6 & $\begin{array}{c}\text { required value } \\
-35.82\end{array}$ & 33 \\
Three & $\begin{array}{c}\text { contrast } \\
\text { rudderpost }\end{array}$ & $\begin{array}{c}\text { prescriptive } \\
\text { value }\end{array}$ & 6 & $\begin{array}{c}\text { required value } \\
+7.45\end{array}$ & 11 \\
-bending & rudderpost & $\begin{array}{c}\text { prescriptive } \\
\text { value }-1\end{array}$ & 6 & $\begin{array}{c}\text { required value } \\
-28.07\end{array}$ & 27 \\
\hline
\end{tabular}

Table 2. Strength results of the improved rudderpost test.

\begin{tabular}{cccccccc}
\hline Rudderpost & $\begin{array}{c}\text { Sample 1 } \\
(\mathrm{MPa})\end{array}$ & $\begin{array}{c}\text { Sample 2 } \\
(\mathrm{MPa})\end{array}$ & $\begin{array}{c}\text { Sample 3 } \\
(\mathrm{MPa})\end{array}$ & $\begin{array}{c}\text { Sample 4 } \\
(\mathrm{MPa})\end{array}$ & $\begin{array}{c}\text { Sample 5 } \\
(\mathrm{MPa})\end{array}$ & $\begin{array}{c}\text { Mean value } \\
(\mathrm{MPa})\end{array}$ & $\begin{array}{c}\text { Dispersion } \\
\text { coefficient } \\
(\%)\end{array}$ \\
\hline 1\# & $\begin{array}{c}\text { required } \\
\text { value }+14.8\end{array}$ & $\begin{array}{c}\text { required } \\
\text { value }+26.5\end{array}$ & $\begin{array}{c}\text { required } \\
\text { value }-5.8\end{array}$ & $\begin{array}{c}\text { required } \\
\text { value }+34.5\end{array}$ & $\begin{array}{c}\text { required } \\
\text { value }+29.2\end{array}$ & $\begin{array}{c}\text { required } \\
\text { value }+19.8\end{array}$ & 15 \\
$2 \#$ & $\begin{array}{c}\text { required } \\
\text { value }+39.8 \\
\text { required } \\
\text { value }+58.3\end{array}$ & $\begin{array}{c}\text { required } \\
\text { value }+12.7\end{array}$ & $\begin{array}{c}\text { required } \\
\text { value }+37.1\end{array}$ & $\begin{array}{c}\text { required } \\
\text { value }+26.5\end{array}$ & $\begin{array}{c}\text { required } \\
\text { value }+34.9\end{array}$ & 14 \\
\hline
\end{tabular}

Table 3. Experimental results of the bending torsion heat of the rudderpost after the process improvement.

\begin{tabular}{cccc}
\hline Rudderpost & $\begin{array}{c}\text { Temperature } \\
\left({ }^{\circ} \mathrm{C}\right)\end{array}$ & $\begin{array}{c}\text { Damaged torque } \\
(\mathrm{N} \cdot \mathrm{m})\end{array}$ & $\begin{array}{c}\text { Damaged moment } \\
(\mathrm{N} \cdot \mathrm{m})\end{array}$ \\
\hline $4 \#$ & required values -19 & required values & required values +493 \\
$5 \#$ & required values -3 & required values +100 & required values +520 \\
$6 \#$ & required values +75 & required values +259.8 & required values +299 \\
\hline
\end{tabular}

The corresponding coefficient can $K=\frac{\bar{x}-L}{s}$, be got $K=3.63$.

According to $\gamma=0.7, n=3$, check GB/T 4885-2009 appendix A available: $R_{L}=0.95$, that is, the rudderpost products at the confidence level $\gamma=0.7$, the lower confidence limit for the reliability of 0.95 .

\section{Conclusion}

Due to $\mathrm{C} / \mathrm{SiC}$ rudderpost abnormal fracture problems, much work for investigation and analysis were done to improve the product quality, several improvements on the procedure were suggested and the samples under improved procedures show much better properties than the samples under traditional procedures.

\section{References}

[1] Krenkel, W. (2001) Cost Effective Processing of CMC Composites by Melt Infiltra- 
tion (LSI-Process). Ceram Eng Sci Proc, 22, 443-454.

https://doi.org/10.1002/9780470294680.ch52

[2] Zhang, L.-T., Cheng, L.-F. and Xu, Y.-D. (2003) Progress in Research Work of New CMC-SiC. Aeronautical Manufacturing Technology, 1, 24-32.

[3] Ran, L.-P., Yi, M.-Z. and Chen, B. (2005) Influence of Different C/C Performs on Microstructure of C/C-SiC Composites Fabricated by RMI C/C. The Chinese Journal of Nonferrous Metals, 15, 1208-1213.

[4] Kim, B.G., Choi, Y., Lee, J.W., et al. (2000) Characterization of a Silicon Carbide Thin Layer Prepared by a Self-Propagation High Temperature Synthesis Reaction. Thin Solid Films, 375, 82-86. https://doi.org/10.1016/S0040-6090(00)01266-9

[5] Yan, Z.-Q., Xiong, X., Xiao, P., Jiang, S.-Z. and Huang, B.-Y. (2007) Non-Isothermal Oxidation Behavior of $\mathrm{C} / \mathrm{SiC}$ Composites Rapidly Prepared by Molten Silicon Infiltration Technique. The Chinese Journal of Nonferrous Metals, 17, 1597-1603.

Submit or recommend next manuscript to SCIRP and we will provide best service for you:

Accepting pre-submission inquiries through Email, Facebook, LinkedIn, Twitter, etc. A wide selection of journals (inclusive of 9 subjects, more than 200 journals)

Providing 24-hour high-quality service

User-friendly online submission system

Fair and swift peer-review system

Efficient typesetting and proofreading procedure

Display of the result of downloads and visits, as well as the number of cited articles Maximum dissemination of your research work

Submit your manuscript at: http://papersubmission.scirp.org/

Or contact msce@scirp.org 